\title{
University of New Brunswick
}

\section{UNB offers two new degree programs}

The Faulty of Forestry and Environmental Management, together with the Faculty of Science at the University of New Brunswick will offer a new Bachelor of Science in Environment and Natural Resources (BScENR) degree program starting this autumn. The goal of the program is to create tomorrow's professional environmental and natural resource managers, scientists, and advocates. Students can choose to major in Water Resources Management, Wildlife Conservation, or Environmental Management. Integration across these specializations occurs through a series of systems-based courses that introduce students to biological, physical, engineering, and socio-cultural systems thinking. These are followed by courses that integrate systems across disciplines using realworld, natural resource problems in an individual and multi-disciplinary teambased learning environment. The overall emphasis of the program is knowledge acquisition and use through practical experience. Students will develop the skills required to characterize, analyze, predict change (real and potential), and synthesize information into comprehensive solutions that respect multiple perspectives and demonstrate appropriate stewardship of environmental and natural resources. Graduates will be able to identify and offer solutions to environmental and natural resource problems from an holistic, systems perspective, incorporating their knowledge of land, water, air, plants, animals, and people. For further information contact Yolanda Spithoven, Outreach Coordinator for the Faculty at (506) 458-7701, or e-mail yolanda@unb.ca.

There is a pressing need for professionals with integrated knowledge of biophysical and socio-economic aspects of environmental problems. UNB is offering a new, course-based Masters in Environmental Management to train such professionals. This program will provide students with an integrated theoretical grounding in bio-

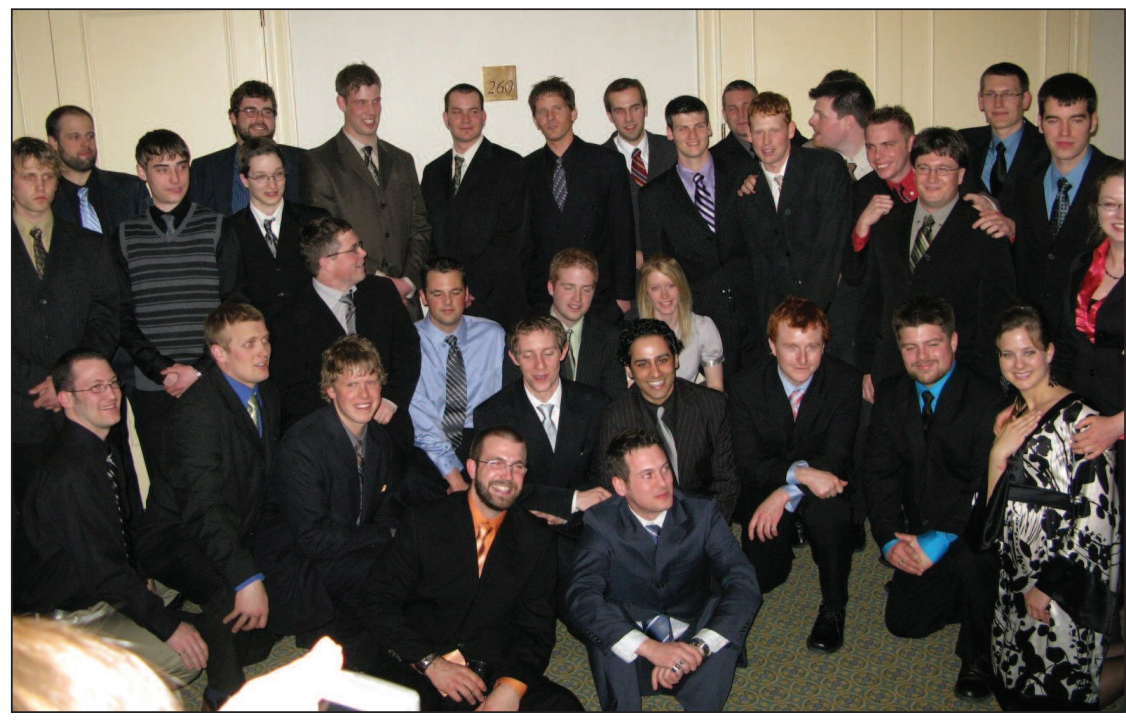

The UNB Forestry Class of 2008.

physical and social sciences, together with critical tools for assessment, communication, and management so they can fully investigate, report on and contribute to the management of the reciprocal relationships between human activities and biophysical systems. The program takes 16 months and features coursework in social ecology, policy, ecosystem dynamics, research methods, economics, and environmental impact assessment. Students with an undergraduate degree in science, forestry, environmental studies, or social science from a recognized university are invited to apply. Students require at least a 3.0 GPA and priority will be given to students who apply by March $1^{\text {st; }}$; later applicants will be considered on an available-space basis. Graduates from the program will be prepared to work in the private and public sectors in environmental impact assessment, integrated natural resource management, resource-based industries and environmental consulting.

\section{New Course for Polarimetric SAR Images}

If you would like to learn how to use polarimetric SAR images (particularly the new RADARSAT-2 images), if you would like to have this learning from your desktop without traveling, then you might be interested in a new online course images (FOR 4304). The course outline is available at http://extend.unb. ca/oalp/courses/for4304.php

The course is open any time and is divided into nine modules to be completed over a period of maximum six months. At the end of the course, you will get a university certificate. It is also available as a non-credit or as a graduate course. La version française du cours sera disponible en septembre.

\section{Acadian Forest variant of Forest Vegetation Simulator}

John Kershaw and Aaron Weiskittel of the University of Maine, along with a team of scientists from Canada and the USA are working on developing an Acadian Forest variant of the Forest Vegetation Simulator. The new model will provide state-of-the-art forest growth and yield forecasting for the Acadian Forest Region. In addition to developing the model, a new interface, which provides flexibility and seemless integration with forest management planning software is being developed. The new interface will work with all FVS variants that currently work with Suppose. 


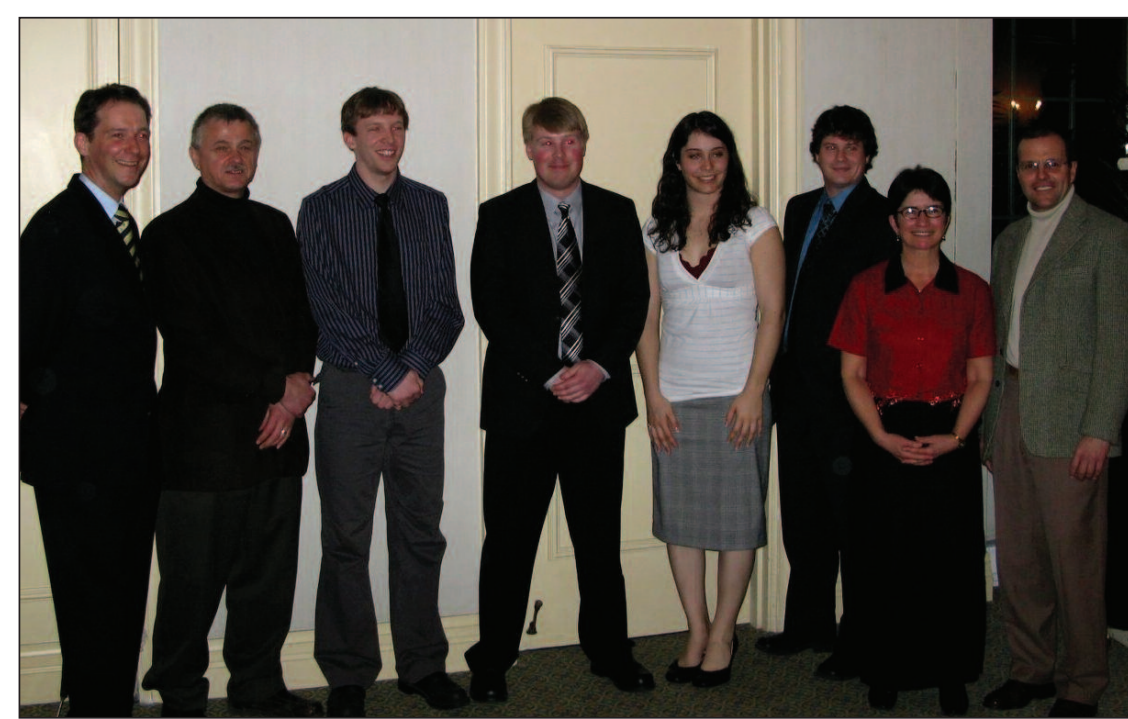

The UNB Forest Engineering Class of 2008.

\section{Canada's Forest Engineering Program only at UNB}

Why did the overflow channel of a pond retaining dam on UNB forest lands experience severe wash out? Is the structure still safe to operate? What needs to be done to avoid further damage and release of sediments into the nearby stream?

Students in their final year at UNB's Forest Engineering (FE) program were asked these questions in the recently established core course, "Structural Design of Forest Engineering Systems." The UNB program is the only FE undergraduate program accredited by the Canadian Engineering Accreditation Board that allows graduates to qualify for P.Eng. designation. It is also unique in its use of learning outcomes. One of the main outcomes of this redesigned four-year program is that students become able to design and analyze structures occurring in natural environments.

In order to create learning opportunities around this outcome and allow students to demonstrate competence in it, they analyze and design structures like forest roads, culverts, embankments, small dams, and short-span bridges in a forest environment. Each year students are confronted with an actual problem to explore and define exactly what the problem is; they consider problem-solving strategies, come up with a solution and assess the solution. Problems are solved in an integrative approach, which means not only applying technical knowledge and skills to solve the problem, but also evaluating the problem and possible solutions with respect to economic, ecologic and social impacts. Students get to understand the full range of impacts related to the problem and design a viable solution, which embraces all mentioned aspects.

For more information about UNB Forest Engineering, see www.forest engineering.unb.ca or contact Prof. Dirk Jaeger at jaeger@unb.ca.

\section{Gold Medal Winner}

Nadia Kovachis grew up in Thunder Bay, Ontario. While at UNB she held executive positions in the Forest Engineering Student Association as treasurer for two years and president for one year. She was renowned for establishing a high esprit-de-corps among students by directing student orientation, hosting student-faculty activities and competing with the UNB/STU Rowing Club. Her summer jobs included guiding wilderness canoe trips in Northern Ontario, working on a layout crew in northern B.C. and supervising a forest road construction project in New Brunswick. Nadia will be returning for graduate studies at the University of Alberta in September after spending the summer with an engineering consulting company in Thunder Bay.

\section{UNB Centennial Conference: Celebrating Alumni Success}

The Centennial Conference (February 21-22) had 23 alumni speakers address

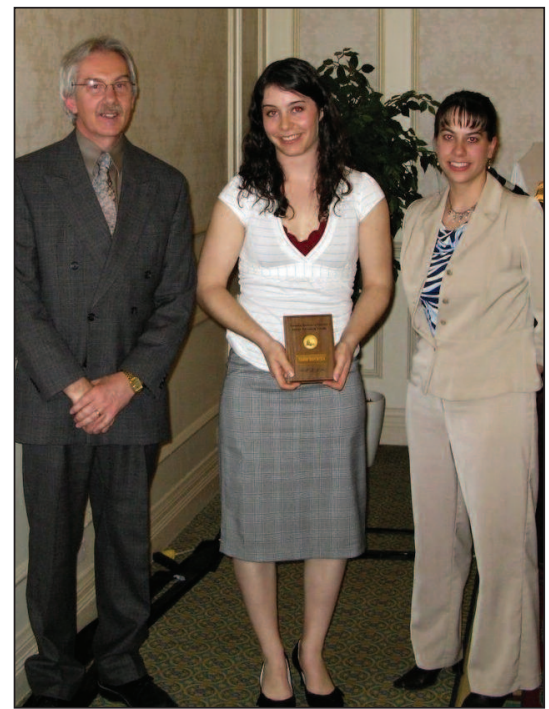

Nadia Kovachis (centre) with Dean Dave Maclean and CIF/IFC 2nd Vice-President, Anne LeBrun Ruff.

students, faculty, and other professionals and alumni at the Wu Conference Center in Fredericton. UNB President John McLaughlin and New Brunswick Department of Natural Resources Deputy Minister Tom Reid (BScF 1972) opened the Conference. All the following speakers were UNB forestry or forest engineering alumni selected to provide a variety of career paths, stages of career, disciplines, and outlook on future directions for forestry and forest engineering.

Our sincere thanks to all speakers, many who traveled long distances to participate. Feedback about the conference was unanimously positive, from students and other attendees, and the Faculty plans to hold similar format conferences (albeit probably one day in length) every two years in the future. Presentations by four UNB alumni speakers are presented.

- Andrea Feunekes, MScF'88; President \& Co-CEO, Remsoft Inc.

- Dr. Anthony Davis, BScF'01, MSc'03, PhD'06 Purdue; Assistant Professor, Dept. Forest Resources, University of Idaho (native plant regeneration and silviculture)

- Hamish Kerr, BScF'77, MBA U. West ON'83; Vice President Strategic Planning \& Forest Policy, TimberWest Forest Corp., Vancouver

- Dr. Judy Loo, BScF'79, MSF'83, PhD'86 Oklahoma State; Research Scientist, CFS-Atlantic, Fredericton. 
Opportunities and Careers in the Forestry Sector and Advanced Analytics Technology

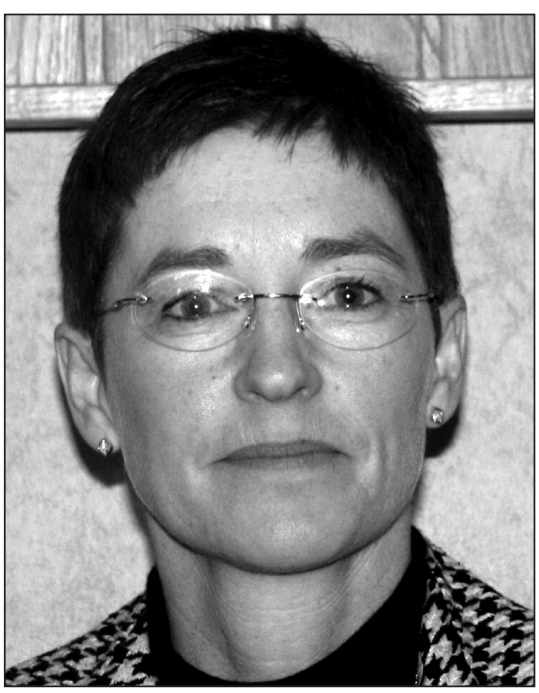

Andrea Feunekes, President and Co-CEO, Remsoft Inc

Remsoft develops software known in main stream business as "Advanced Analytics," essentially software for strategic and operational level planning that uses data as well as things like linear programming, simulation, GIS, and a lot of smarts to help people plan better. Because the challenges of balancing many competing objectives and constraints are so complex, the potential in terms of what these kinds of tools can do in the field of forestry is virtually unlimited.

These are some very advanced analytics, and Canadian foresters have been doing this kind of thing for years, decades even. Foresters are "way ahead of the curve" and what you are learning in school is very relevant-you are well positioned for the future-your skills are broadly applicable. With that as a background I'd like to talk about opportunities and careers in the forestry sector, particularly as they pertain to forest management and planning, and technology at the level of Advanced Analytics.

Every year we survey the people who use our software-and they are in the hundreds around the world. We gather a lot of data that is useful in product development, but there is also a lot of information on who they are and what they do. They are working as strategic planners in Nature Conservancies, as Crown Land Managers, as Timberland Investment analysts, plantation managers; there are even some Vice Presidents of Banks. To begin, broadly speaking, their job titles fit the following categories:
Forest Analyst

Senior Resource Planning Analyst

Planning Forester

Harvest Scheduling Analyst

Crown land Forester

Business Analyst

Forest Economist

Estate Planner

Timberland Asset Manager

Forest Investment Manager

Performance Analyst

Senior Management

VP Operations

Vice President

Superintendent of Forestry

GIS and Technology Specialists

Programmer/Analyst

Manager, Forest Management System

GIS \& Remote Sensing Analyst

Inventory and Other

Inventory Forester

Forest Ecosystem Analyst

Forest Ecologist

Forest Biometrician

\section{Types of Analysis}

Wood supply analysis $86 \%$

Harvest scheduling

Economic analyses

Spatial modeling

Tactical planning

Land valuation

Wildlife, biodiversity issues

Other non-timber analysis

\section{Emerging Issues for Forest Analysts}

Non-timber values $31 \%$

Spatial constraints

$12 \%$

Spatial constraints

$12 \%$

Regulation

$6 \%$

Reporting accountability

$9 \%$

Economics

$9 \%$

Complexity

$20 \%$

Operational constraints

$12 \%$

\section{Non-timber Values in Forest Plans}

- Social license to operate

- Water, watershed management

- Wildlife and wildlife habitat

- Natural disturbance

- Biodiversity

- Combining "biologic" and financial feasibility in the same models

- Mountain pine beetle

- Carbon
Forest analysts have a responsibility to communicate their work to a broad spectrum of people. Our clients deal with scrutiny from diverse stakeholders, certification, public perceptions, increasing legislation and explaining why modeling is not an exact science to "financial" owners. Who they communicate with:

$\begin{array}{ll}\text { Supervisor } & 65 \% \\ \text { District, regions } & 57 \% \\ \text { Biologists and specialists } & 37 \% \\ \text { Shareholders } & 20 \% \\ \text { External stakeholders } & 34 \% \\ \text { The public } & 32 \% \\ \text { Auditors } & 26 \%\end{array}$

In terms of non-timber values, we learned that, "everyone" is thinking about carbon. What they have, what it is worth, what they can do with it, etc. And, there are some extremely complex challenges ahead that will need to be addressed including:

- Social license to operate

- Watershed management

- Wildlife and wildlife habitat

- Natural disturbance

- Combining "biologic" and financial feasibility in the same models In Summary: To the faculty:

- Keep up the cross discipline education!

- Reward analytical thinking, and risktaking in thinking.

- Continue with project-based learning.

- Encourage students to look beyond the faculty to find what they need to solve a problem.

- Bring in more outside resourcesbeyond New Brunswick's borders. And a final note to the students:

- Don't limit yourself to the traditional thinking of what forestry is and isn't.

- Keep informed about what is going on globally—not just in your backyard.

- Join the main-stream, connect to business, the boardroom and the public.

This is a great industry with a high concentration of good, decent people who care about their world and are fantastic to deal with on a day-to-day basis.

\section{UNB Forestry and Me: Career- Forming Education and my Vision for the Future}

Graduating from the Faculty of Forestry and Environmental Management at UNB has, as one would expect, had a profound impact on my career. Everyday decisions I make are often rooted in 


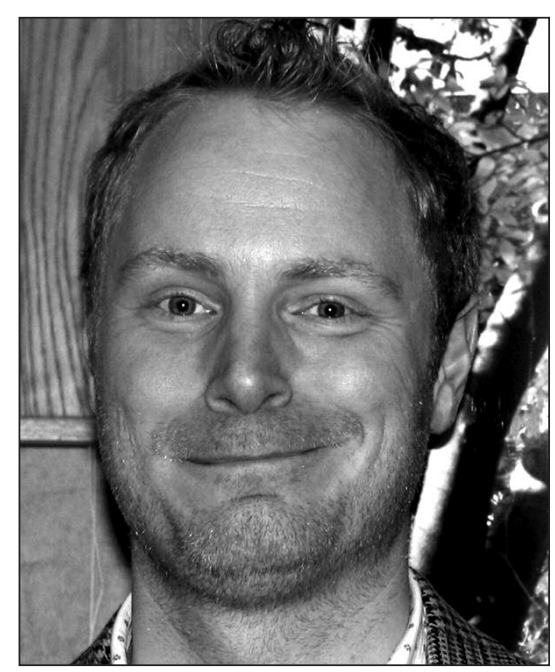

Anthony S. Davis, Asst. Professor, Dept. of Forest Resources, University of Idaho.

the lessons learned as an undergraduate in Fredericton. As we celebrate a century of forestry education I am pleased to have been asked to take the time to reflect on how my experiences at UNB have affected me as a researcher, an educator, and a contributing member of society.

Currently, I am an Assistant Professor in the field of native plant regeneration and silviculture at the University of Idaho. In this capacity, I conduct research, teach courses, and transfer technology relevant to my field. As part of my faculty appointment, I am also the Director of the Center for Forest Nursery and Seedling Research that manages the Franklin H. Pitkin Forest Nursery and related research facilities.

How I got here: The path I took to end up in this position is actually somewhat logical, although it has involved three degrees, two countries, and a genuine passion for my work. A quick glance at the current location of UNB FOREM graduates can tell us that we are quite mobile. My path involved a year in Dryden, Ontario immediately after graduation where I worked for PRT, Inc. as a seedling grower-trainee. After that year, I realized that there were many burning questions regarding seedling production that I wanted to answer. So graduate school beckoned me, and I decided on Purdue University in Indiana, at the Hardwood Tree Improvement and Regeneration Center. Over the next few years, I conducted research and taught courses, until graduating with a $\mathrm{PhD}$ and faced once again with having to look for full-time gainful employment. Having enjoyed the combination of research and teaching, I knew what I was looking for in a career, and looked at postings for academic faculty positions. Deciding where to seek employment was not only based on the match between the position description and my specific skill set and interests, but also the academic culture of the institution itself, as influenced largely by my experiences at UNB Fredericton and Purdue University. I knew I was best suited to an institution that valued academic freedom and creativity. Further, the size of both the forestry program and the University, the role and name recognition of the program within the University, and the reputation among those who employ our graduates and those who fund our research were the key tenets of any program with which I wanted to be associated. The University of Idaho is of a comparable size and institutional nature, and has a similar regional reputation to UNB, and the position I took fit well with my career interests and objectives.

How UNB Forestry contributed to my career: As an undergraduate at UNB or any university, there are myriad factors that determine whether one is successful or not; the demand on undergraduate students is high. Academically, there is a lot of new material that builds on concepts and certain levels of understanding. Socially, there is pressure to fit in, make friends, and be part of a network. For me, at its best, UNB forestry provided a number of ways that allowed students to overcome difficulties in those two areas. Through a diverse set of learning methods (classes, computer labs, outdoor labs, and projects) students are forced to work with each other. The science library becomes a hangout, the computer lab a place to meet for both social and academic duties; being a relatively small, walkable, city provides many other comforts as well. But perhaps most importantly, understanding, diverse, and approachable faculty members create a sense of partnership in education.

This mutual respect between students and professors is necessary. UNB Forestry has often been an innovator in forestry education and, without respect, students are leery of new evaluation methods, and professors are less enthusiastic about trying them. Outcomebased learning provides a tangible set of skills that can be applied to a diverse set of careers, and through continued feedback allows a program to keep up with current and anticipated future skills needed by graduates. Continuing to evolve and incorporate new learning methods and tools where appropriate is necessary to remain a top-tier program. Feedback from current students, recent graduates, employers, and other parties will maintain this, and for that feedback to be honest and effective it must be built on a foundation of respect.

What I have learned: Through my experience as a student within, and since being away from, UNB FOREM, there are four things I have "learned." I believe that these contribute to my success and are important components to building a successful program.

They are:

Endowments: key to financial independence at public universities. Not having to worry about financial security allows a program to focus on creative problem-solving, a necessary endeavour for the continued viability of today's forest industry. Industry partnerships and alumni involvement, as at this centennial celebration, are useful steps in this direction.

Passion: by students, staff, and faculty, is irreplaceable. It is necessary to maintain the type of energy and determination demanded by a career in forestry and to inspire the next generation of leaders.

Strong ethics are the backbone to making decisions under pressure. Performance in stressful situations can define a legacy; if one has a strong sense of ethics, decision-making under pressure can easier.

Creativity is often the key to finding effective solutions to questions or problems. Whenever possible, see how others approach problems; think about how these approaches might apply to your situation, and be creative.

The future: Those of us involved in the forest nursery profession are concerned about the lack of new recruits to the field. In my current position, I am hoping to increase educational opportunities pertaining to nursery production through distance learning programs and a minor associated with our Forest Resources degree. At the University of Idaho, we have added Forest Regeneration as a core course at the junior level. Continuing to refine our program to better prepare graduates for their next 
step is part of our strategic plan. Identifying methods to improve recruitment is also a continuous challenge we must deal with as enrolment in forestry programs has decreased over the past few years. Summer internships can be useful for recruiting into forestry. Willingness to implement creative solutions, on the part of both educators and employers, is needed to fully overcome the problem of recruitment into our field.

These are trying times for commercial forestry in New Brunswick, and throughout North America. I believe that UNB Forestry has a key role to play; locally, that role is to help drive the forestry sector in New Brunswick, and not just be a passenger. This is done through the development of strong science and management leaders with potent undergraduate curricula, and with research and graduate programs that develop new methods and products. On a broader scale, these same needs and opportunities persist, particularly in terms of sharing expertise on an international scale. Looking at alumni speakers in this conference, and at the list of graduates of our programs, we know UNB Foresters are leaders. Continuing to develop leaders as successfully as in the past will only become more difficult and thus success requires an eclectic mix of creativity, intelligence, passion, stubbornness, and of course hard work. To me, this is exactly the type of challenge that UNB Forestry has a history of surmounting.

\section{Presentation to UNB Forestry Centennial Conference}

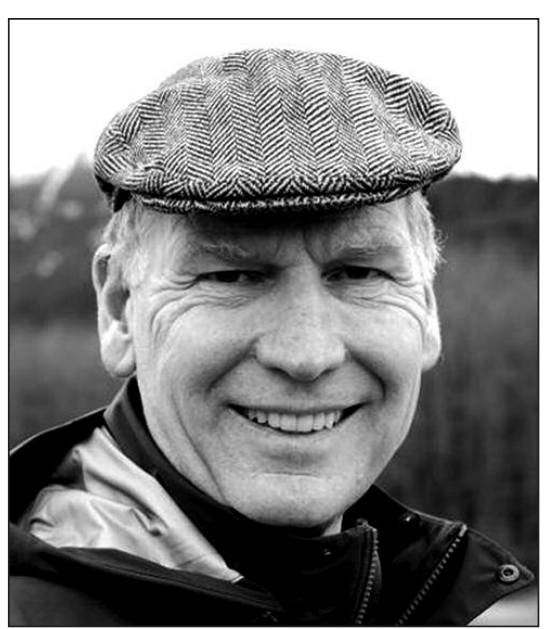

Hamish Kerr, Vice-President, Strategic Planning and Forest Policy, TimberWest Corp., Vancouver.
I stumbled into forestry. I knew what I didn't want to do and in the end was guided by a love for the outdoors and a pragmatic attitude that it didn't matter too much what I did because there would be some niche within that field that would be right for me. Forestry is great because in the early years you cover so many subjects. I fell in love with economics and it has shaped the rest of my career. Another highlight was participating in the third-year exchange program with the University of Maine at Orono. I enjoy travel and seeing how other people do things. When I graduated I took the only job offer received, which was from MacMillan Bloedel on Vancouver Island. I went west because it was exotic, the pay was higher, and the fact there were virtually no bugs in the woods was a bonus.

My summer jobs while at UNB were quite varied. I love to travel so I didn't pursue jobs in the Maritimes or central Canada. My only summer job through a campus interview was timber cruising in northern Alberta. The rest of the summers I struck out on my own and worked construction in the arctic, on a survey crew in Alberta and at a sawmill in the BC Interior. I got the job at MacMillan Bloedel (MB) by going to Vancouver just before starting my final year and getting "informational" interviews with all the Chief Foresters. They all made time to see me. I like to think I got the job at MB because my background of getting a variety of summer jobs on my own initiative and my third year at Maine made me different from the rest of the pack.

I worked as a field forester for four years and found I enjoyed the business aspects more than the fieldwork. When I applied and failed to get a more business-oriented job at MB, I took matters into my own hands and went back to get an MBA. My intention was to come back to $\mathrm{BC}$ to run a logging division or sawmill. I graduated with my MBA in 1983 during a severe economic downturn. There were no forest industry jobs. My wife was pregnant with our first child and our bank account was drained so "I sucked it up" and took a job as a forest analyst with an investment dealer in Toronto. I worked as a forest analyst covering Canadian forest companies for institutional investors for almost 18 years eventually moving to a smaller dealer in Vancouver in 1992. It was the perfect job for me as I was able to learn more about the global forest industry than most participants and the investment game is a pretty exciting one. However, I eventually got bored of doing essentially the same thing. I took some time off and discovered I had more loyalty to the forest industry than the investment industry. I took my current job in 2001 and have had tremendous fun working with very talented people (even if most are UBC graduates) increasing the value of TimberWest.

I have had a successful career but a career is only one part of a happy life. The three things that seem to have a bearing on happiness are having family and friends, being good at something and having some degree of autonomy. The forestry degree meant getting to know a small group of people quite well because we took most of our classes together. I don't see many of my classmates often, but when we get together we pick up right where we left off. I found economics/business was something I was good at when I was at UNB and it has shaped my career. You need to find something you like and work on getting better. Autonomy means having some control over your time. If you are not getting what you want then initiate change, even though it can be scary. In each case that I changed it turned out for the better.

Where is forestry going in the 21st century? I think the Canadian forest industry is a sunset industry and that future jobs connected with the forest could involve managing it in the absence of intensive harvesting. I have used "weasel" words like "I think" because the future is unknowable. However, if you look at history combined with economic principles that have stood the test of time we can make an educated guess. The comparative advantage for producing fibre has moved to the southern hemisphere. Brazil has softwood fibre growth rates almost ten times those found in most of Canada and the hardwoods grow even faster. In Canada planting is a cost of doing business but in much of the southern hemisphere it is an investment that yields a positive return. Short rotations in the southern hemisphere are one of the main reasons for its financial success. Research in genetics, fertilization and the use of herbicides are only going to increase the southern hemisphere advantage. The Canadian industry in aggregate does not earn its cost of 
capital according to surveys done by PriceWaterhouseCoopers, which is another way of saying that Canada would be better off if the capital and employees devoted to the forest industry were deployed in other industries where returns are higher. The northern hemisphere pulp and paper industry looks like it is shrinking to a niche industry already. The sawmilling industry is not there yet, but with advent of engineered wood products I suspect that the southern hemisphere will make inroads over the ensuing decades. The best analogy to what is happening in Canadian forestry right now is with agriculture a hundred years ago where the amount of cultivated land in the Maritimes and New England has fallen as better agricultural areas in the midwest combined with cheap rail transport shifted the comparative advantage and financial returns westward. The old stone fence lines in the UNB forest bear witness to an agricultural past before the land was abandoned to trees.

The future could be in the land management function for social needs and I think the Forestry Faculty has acknowledged this shift by adding Environmen- tal Management to its name. There are many public goods that are being demanded of forests and we enhance most of them by manipulating the forest.

What does this mean for you? Well, the first bit of advice is to be flexible. The forest industry will not disappear overnight, but be ready to roll with the punches. Get skills that are transferable to other industries or regions and don't be scared to move geographically. I never dreamed I would live in Toronto but it wasn't nearly as bad as I imagined and I eventually got where I wanted. I have written this from an industry slant, but there are lots of jobs managing timberland that do not involve industrial forestry. And, of course, I could be wrong about the sunset industry, but don't count on it.

\section{Presentation at the 100-year Forestry UNB Conference}

The five years (1974-79) spent as a forestry student at UNB have stood me in good stead. Lasting legacies of those years include a solid base in forest and biological science, leadership skills developed through involvement in many extracurricular activities, and

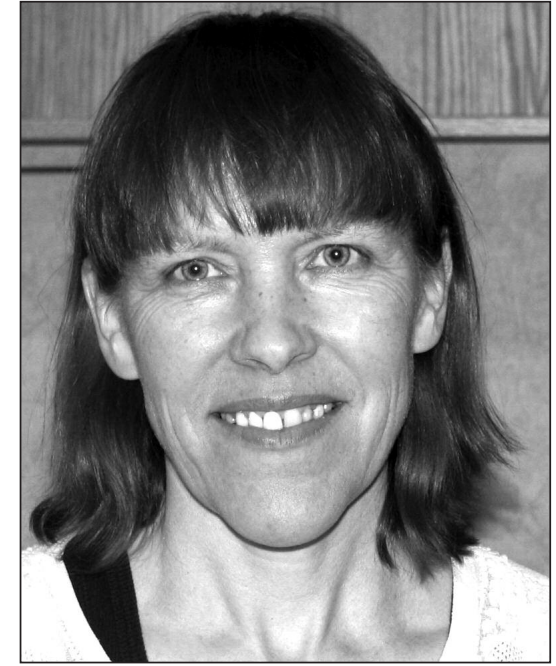

Dr. Judy Loo, Research Scientist, CFSAtlantic, Fredricton

enduring friendships. The decision to study forestry at UNB was almost accidental. I had grown up with a love for trees and had spent many of my spare hours in the woods, so when a UNB recruiter at my high school on PEI presented the idea of spending time in the woods and being paid for it, the appeal was strong and immediate.

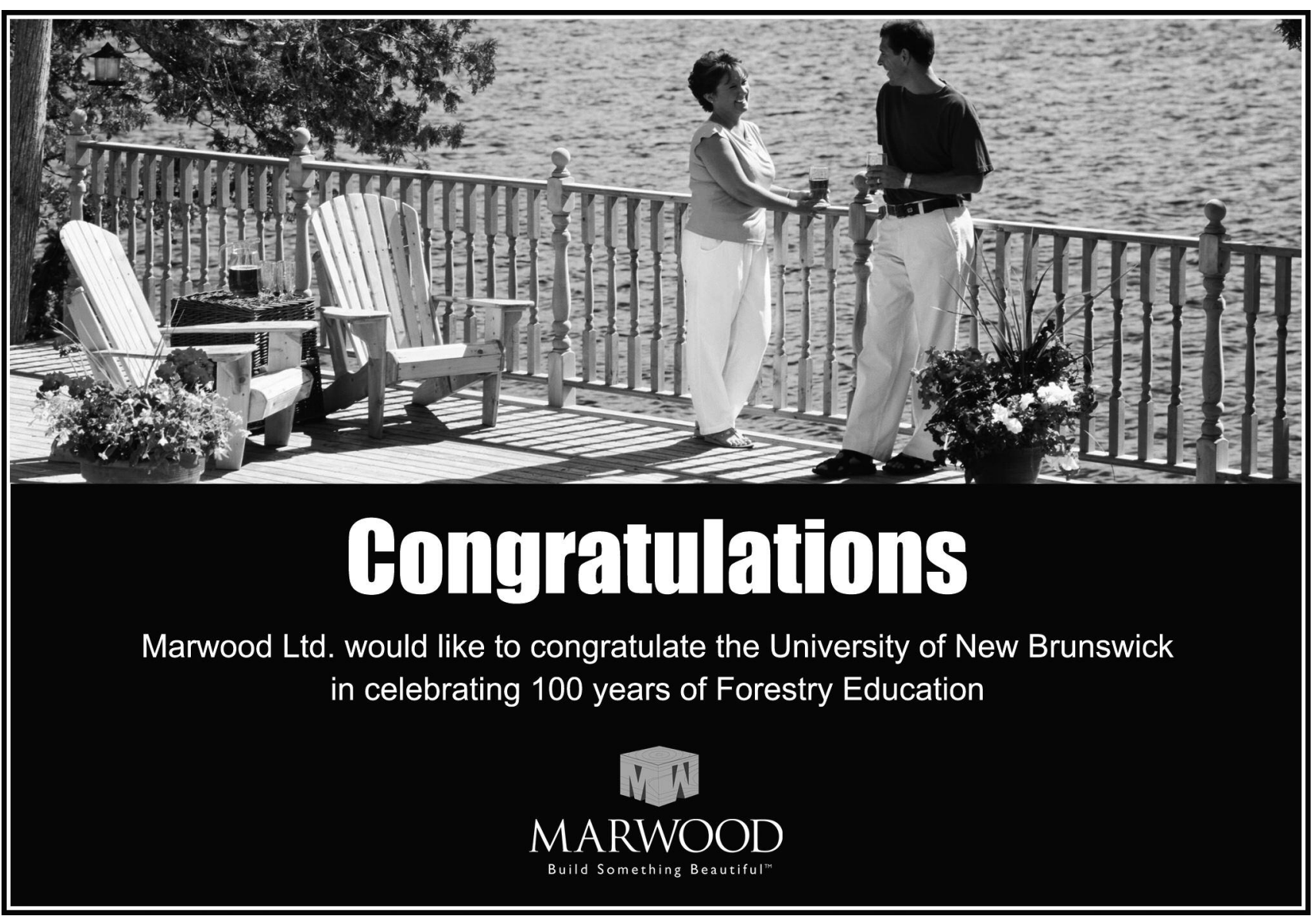


At UNB, I followed the "Forest Biology" stream and became especially interested in genetics and ecology. For two summers, I worked with the genetics group at CFS; Dr. Don Fowler supervised my undergraduate thesis. This experience had a strong and lasting influence. I was very involved in student life, captain of the first women's woodsmen's team, president of the student Forestry Association one year, forestry rep on the SRC, chair of an environmental awareness committee that took slide shows to schools, and a member of the Coffee House Collective, and the off-campus Maritime Energy Coalition.

After graduation, I bought a train ticket to the Pacific coast and ended up in Prince George, where work was plentiful. By chance, the previous month's Forestry Chronicle had carried a picture of me receiving my forestry ring and I discovered that when I knocked on doors, people recognized my face from the picture. It gave me a foot in the door and within two days, I had been offered two jobs. I did not get a foot in the door everywhere though. Companies could still turn away female foresters with impunity because of policies to avoid hiring women for field positions.

For the next two years I worked for the Ministry of Forests as the "Tree Seed Coordinator" for the northeastern quarter of BC. When I began, I was the only female forester in the region. The work in the Prince George Region was challenging, exciting and fun most of the time. I was fortunate enough to be out of the office about half the time, amidst gorgeous scenery. The most exciting part was assisting the tree improvement group to collect scions for establishing seed orchards. We did it by helicopter, flying into areas with no roads and collecting treetops while the helicopter hovered.

I was also the region's rep at the provincial tree improvement meetings, where it was a distinct disadvantage to

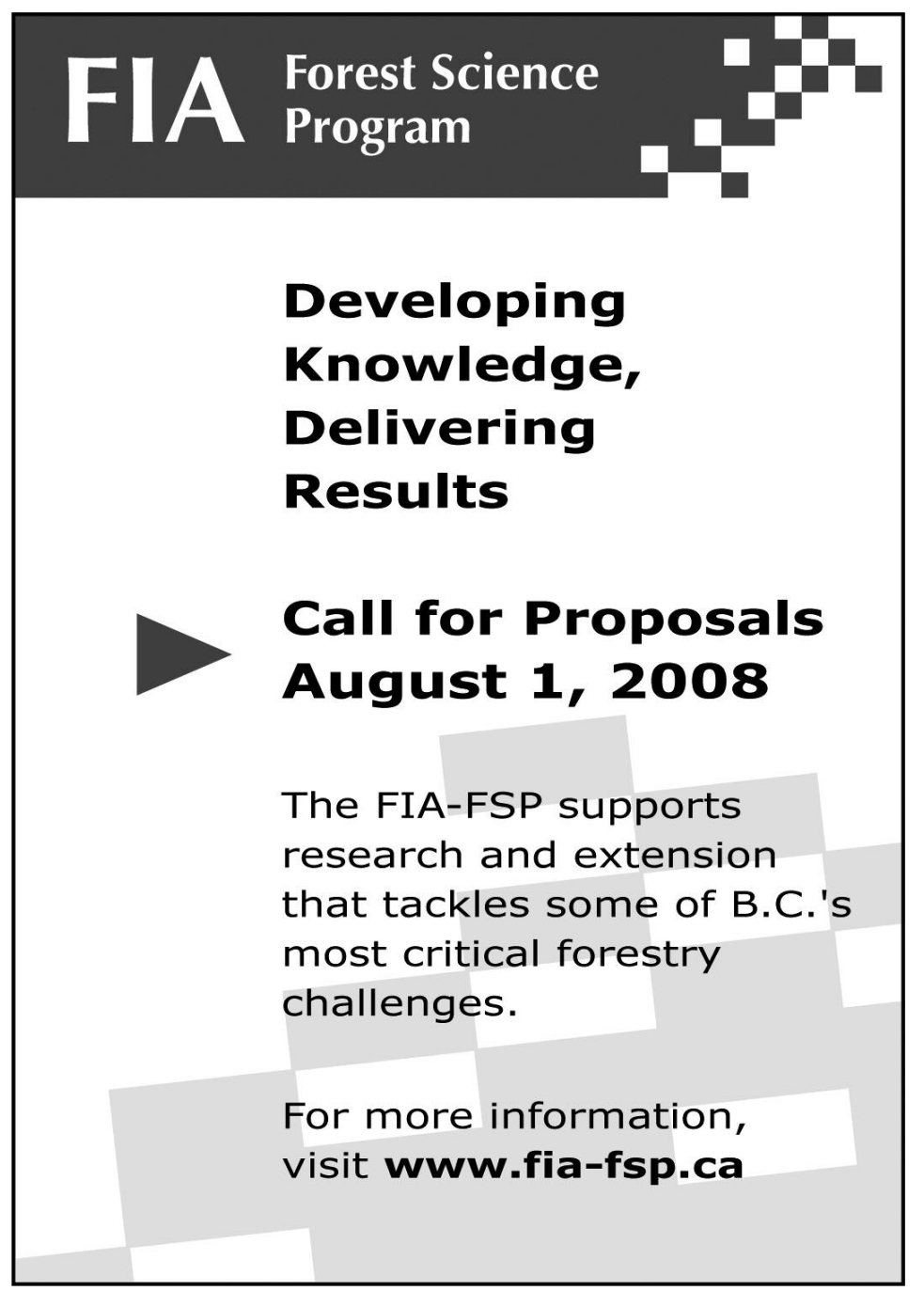

be the youngest person, the only one without at least a master's degree, and a woman. There were often suggestions that I should take the notes. By the end of the first year, I knew that I had to go back to school if I wanted to be taken seriously in tree improvement circles and that I needed to strengthen my quantitative skills. So I went to the North American Quantitative Forest Genetics Workshop, which was in Idaho that year, and shopped for a graduate school. A professor I met there, Dr. Chuck Tauer at Oklahoma State University, called me a few days after the workshop to tell me that he had a stipend for me to do the research that I wanted to do. So two years after arriving in Prince George by train, I loaded all my worldly possessions into the back of my pickup truck and drove to Stillwater, Oklahoma.

Spring and early summer weather in Prince George had been cold, with the temperature never breaking $20^{\circ} \mathrm{C}$. Oklahoma was in the midst of a heat wave when I arrived, with temperatures around $100^{\circ} \mathrm{F}$ for the next two weeks. I was not sure that I would survive the heat, but I learned to love it. I soon discovered that UNB had prepared me very well for graduate work; in fact, my supervisor told me that he would take any student he could get from Canada. After completing my masters degree and discovering that loblolly pine showed heritable variation in the timing of transition from juvenile to mature wood, I went on to complete a $\mathrm{PhD}$ on methods to improve the estimation of breeding values in progeny tests having high site variability.

Less than six years after leaving BC, I returned to accept a research associate position at UBC with Dr. Don Lester, a forest geneticist who held an NSERC Industrial chair. As a research associate, I had a mixture of duties, developing some research of my own, teaching and helping to supervise graduate students, and assisting with Don's research program. It was varied work, challenging and stimulating. My daughters were born in Vancouver and although the country was gorgeous and there was plenty of work, I missed the east, because now that I had babies, I began to miss community. Real community is easier to find in the Maritimes than in any big city, and when the opportunity came to move back to Fredericton as a research scientist with CFS, I took it. 
At that time, the world was preparing for the great environmental summit of 1992 in Rio and it provided an opportunity to make my work more meaningful personally. I continued working in genetics but shifted my focus mainly to conserving and using genetic diversity of tree species; developing gene conservation guidelines and working on genetic resistance of beech-to-beech bark disease. My work has included developing criteria and indicators of sustainable forest management, identifying natural areas that require protection, describing historical conditions of the Acadian forest, contributing to guidelines to maintain forest biodiversity, and working on a project in Mexico to conserve genetic resources, including teaching short courses there.

I have made a gradual transition in my career and have come back to where I started, motivated primarily by love for the forest and for humanity. The only advice I would offer students today is to follow your hearts; discover what really matters to you and find a way to do it.

\section{PROFESSIONAL ASSOGIATION NEUSS * NOUUELLES DES ASSOGIATIONS PROFESSIONNELLES}

\section{Association of Registered Professional Foresters of New Brunswick}

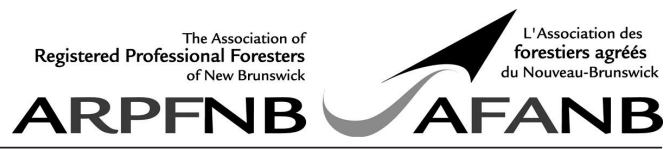

W hat do you get when half a dozen retired New Brunswick RPFs get together? Talk begins with reminiscences of days spent at the University of New Brunswick, stories about fellow forestry students, favourite professors, and about stealing cannons and painting Beaverbrook. Our ties with the UNB Faculty of Forestry date back to our inception.

The Association of Registered Foresters of New Brunswick, as it was then titled, was brought into being on April $2^{\text {nd }}, 1937$, although our official Charter was not presented until November $30^{\text {th }}, 1939$. The first question of where to display the large framed document was quickly solved; it was originally placed in the office of the Dean of Forestry at UNB.

Stated purposes of the newly formed Association are as relevant now as they were 71 years ago:

- To promote sound forestry practice in New Brunswick;

- To promote a better mutual acquaintance among New Brunswick foresters; and

- To cultivate an esprit de corps among members of the profession.

One could argue that promoting better mutual acquaintance may not have been entirely necessary in those first years. Most members had come through the UNB forestry program and were probably already well acquainted with one another. Many early members, however, were knowledgeable foresters without formal training. When the Act was proclaimed foresters with 10 years of experience in forestry, and of good moral character (not a trait required of university graduates applying for admission) were welcomed into the Association without further examination. Following passage of the Act, experienced foresters without degrees were required to submit a thesis and successfully complete an examination before admission was granted.

There was the necessary bureaucratic run-up to officially proclaiming the new Association. One of the first actions was to establish a Board of Examiners to which foresters were required to apply for membership. The Act required a professor from the Department of Forestry at UNB to serve as chair, and additional members to include either the Minister or Deputy Minister of Lands and Mines, two RPFs, and a third forester from the provincial department. At the second Board of Examiners meeting on October $16^{\text {th }}$ 1937, thirty-four applications for membership were approved; the first New Brunswick Registered Foresters, although only 23 of these were listed as charter members.

Seventeen of the original 23 charter members were $\mathrm{BScF}$ graduates from UNB; others were from the University of Toronto, the Norwegian College of Agriculture and Forestry, and the Ranger School in New York State. At the time, charter members were employed by the Province of New Brunswick (Department of Lands and Mines), industry (Frasers, Bathurst Power and Paper, New Brunswick International Paper, and the New Brunswick Railroad Company), the Federal Government, and the University of New Brunswick.

In those early days, the Association played an active role in preparing reports and recommendations on a broad range of forestry issues including forest protection, road access for fighting fires, forest insect control, inventory planning and the establishment of a Ranger School. The City of Fredericton received knowledgeable advice on protection of the city woodlot, also known as the Odell estate.

Interestingly, the original legislation conferred right to practice on the province's foresters, clearly stating that: "any person not being a registered or licensed forester in New Brunswick ... . who practices as a forester . . . shall be guilty of an offence under this Act." Also, foresters from out of province but working in New Brunswick were required to obtain a license from the Association, and were charged a standard fee. These restrictions became problematic within a very short time, as there were fewer than 40 registered foresters in the province, and many of these early members left within the next few years to serve in World War II. The issue of non-members working as foresters, primarily for industry, was discussed in meetings held at that time. Prophetically, the Executive Committee concluded that if they allowed nonforesters to practise in the province 